University of Nebraska - Lincoln

DigitalCommons@University of Nebraska - Lincoln

Publications from USDA-ARS / UNL Faculty

U.S. Department of Agriculture: Agricultural

Research Service, Lincoln, Nebraska

September 1998

\title{
Is Soil Temperature Better than Air Temperature for Predicting Winter Wheat Phenology?
}

Gregory S. McMaster

USDA-ARS, greg.mcmaster@ars.usda.gov

Wallace Wilhelm

University of Nebraska-Lincoln, wwilhelm1@unl.edu

Follow this and additional works at: https://digitalcommons.unl.edu/usdaarsfacpub

Part of the Agricultural Science Commons

McMaster, Gregory S. and Wilhelm, Wallace, "Is Soil Temperature Better than Air Temperature for Predicting Winter Wheat Phenology?" (1998). Publications from USDA-ARS / UNL Faculty. 87. https://digitalcommons.unl.edu/usdaarsfacpub/87

This Article is brought to you for free and open access by the U.S. Department of Agriculture: Agricultural Research Service, Lincoln, Nebraska at DigitalCommons@University of Nebraska - Lincoln. It has been accepted for inclusion in Publications from USDA-ARS / UNL Faculty by an authorized administrator of DigitalCommons@University of Nebraska - Lincoln. 


\title{
Is Soil Temperature Better than Air Temperature for Predicting Winter Wheat Phenology?
}

\author{
Gregory S. McMaster* and Wallace W. Wilhelm
}

\begin{abstract}
In predicting wheat (Triticum aestivum L.) phenology, logic suggests that basing thermal unit accumulation on near-surface soil temperature should give a better representation of shoot apex thermal unit accumulation than air temperature until internode elongation raises the apex above the soil surface. $A$ study was undertaken to determine if predictions of winter wheat phenology are improved when based on measured near-surface soil temperature rather than air temperature. Air temperature $1.5 \mathrm{~m}$ above the soil surface and soil temperature at crown depth (the position of the shoot apex before stem elongation) were collected for 23 site-years across the U.S. Central Great Plains representing a range of cultivars, soils, management practices, and climates. Seven site-years from different sites were randomly selected to calculate the mean thermal units from both seeding and 1 January to specific growth stages based on both air and soil temperature. These means were used to predict occurrence of growth stages for the remaining $\mathbf{1 6}$ site-years. In no instance did soil temperature significantly improve prediction of winter wheat phenology. From these results, we conclude that the additional effort and expense of using soil temperature in predicting winter wheat phenology are not justified.
\end{abstract}

$\mathrm{O}$ NE RECURRING QUEST in wheat phenological research in recent decades has been to better understand the role of temperature and to improve the thermal time concept (reviewed by McMaster, 1997). Most wheat phenological modeling is based on the concept of thermal time and its many modifications and variations, which incorporate factors such as photoperiod, water

G.S. McMaster, USDA-ARS, Great Plains Systems Res., P.O. Box E. Fort Collins, CO 80522 and W.W. Wilhelm, USDA-ARS, Soil and Water Conservation Res., Univ. of Nebraska, East Campus, 119 Keim Hall, Lincoln, NE 68583-0934. *Corresponding author (greg@gpsr. colostate.edu).

Published in Agron. J. 90:602-607 (1998). stress, nutrient stress, upper temperature thresholds, and varying the base temperature (e.g., McMaster et al., 1992; Rickman et al., 1996; Ritchie and Otter, 1985; Weir et al., 1984). Although introduction of other factors can improve the prediction of phenology, temperature remains the primary factor driving wheat development (e.g., Frank and Bauer, 1995; Jamieson et al., 1995; Wilhelm and McMaster, 1995).

Purvis (1961) was one of the first to indicate that the wheat shoot apex directly perceives temperature. Further, the long history of experiments in which roots and shoots are maintained at different temperatures also indicates that the grass shoot apex perceives temperature. See, for example, Kleinendorst and Brouwer, 1970, Watts, 1972, and Bollero et al., 1996, for corn (Zea mays L.); Ong, 1983, for pearl millet [Pennisetum glaucum (L.) R.Br.; syn. P. typhoides (Burm. f.) Stapf \& C.E. Hubb.]; Peacock, 1975, for perennial ryegrass ( $\mathrm{Lol}$ ium perenne L.); and Sato and Ito, 1968, for orchardgrass (Dactylis glomerata L.) and perennial ryegrass.

Thermal time, often expressed in growing degreedays (GDD), is commonly calculated from air temperature, and a constant relationship between air temperature and shoot apex temperature is assumed. The wheat shoot apex is located in the crown of the plant until internode elongation raises the apex above the soil surface. It seems logical that while the shoot apex is in the crown, soil temperature at crown depth might be a better indicator of shoot apex temperature than air temperature. When the shoot apex is elevated above the soil surface, air temperature may be a better measure of apex temperature than soil temperature. Following this

Abbreviations: GDD, growing degree-days; LAI, leaf area index; RMSE, root mean square error; SARES, sum of absolute residuals; SRES, sum of residuals. 
Table 1. Site descriptions, with soil type, wheat cultivar, rotation, and site-year seeding dates.

\begin{tabular}{|c|c|c|c|c|c|c|}
\hline Field site & Lat, Long & Elev. & Soil type & Cultivar & Rot. $\dagger^{\dagger}$ & Seeding dates (with site-year code) $\$$ \\
\hline & & $\mathbf{m}$ & & & & \\
\hline $\begin{array}{l}\text { Fort Collins, CO } \\
\text { Akron, Co }\end{array}$ & $\begin{array}{l}40^{\circ} 36^{\prime} 46^{\prime \prime}, 104^{\circ} 59^{\prime} 42^{\prime \prime} \\
40^{\circ} 09^{\prime} 55^{\prime \prime}, 102^{\circ} 59^{\prime} 16^{\prime \prime}\end{array}$ & $\begin{array}{l}1520 \\
1372\end{array}$ & $\begin{array}{l}\text { Nunn cl (Aridic Argiustolls) } \\
\text { Platner sl (Aridic Paleustolls) }\end{array}$ & $\begin{array}{l}\text { TAM } 107 \\
\text { Centurk }\end{array}$ & $\begin{array}{l}\text { WF } \\
\text { WF }\end{array}$ & $\begin{array}{l}\text { 14 Sept. } 1994(1,2), 12 \text { Sept. } 1995(3,4) \S \\
4 \text { Sept. } 1977(5), 12 \text { Sept. } 1978(6), \mathbb{T} \\
\text { 10 Sept. } 1979 \text { (7), } 20 \text { Sept. } 1980(8)\end{array}$ \\
\hline Albin, WY & $41^{\circ} 27^{\prime} 48^{\prime \prime}, 103^{\circ} 59^{\prime} 43^{\prime \prime}$ & 1463 & Rosebud I (Aridic Argiustolls) & Scout 66 & WF & $\begin{array}{l}27 \text { Aug. } 1977 \text { (9), } 29 \text { Aug. } 1978 \text { (10), } \\
25 \text { Sept. } 1979 \text { (11) }\end{array}$ \\
\hline Paxton, NE & $41^{\circ} 01^{\prime} 48^{\prime \prime}, 101^{\circ} 24^{\prime} 52^{\prime \prime}$ & 988 & Dawes vfsl (Aridic Paleustolls) & Centurk & WF & $\begin{array}{l}14 \text { Sept. } 1977 \text { (12), } 16 \text { Sept. } 1978 \text { (13), } \\
23 \text { Sept. } 1979 \text { (14) }\end{array}$ \\
\hline $\begin{array}{l}\text { Mankato, KS } \\
\text { Tribune, KS }\end{array}$ & $\begin{array}{l}39^{\circ} 49^{\prime} 25^{\prime \prime}, 9^{\circ} 15^{\prime} 00^{\prime \prime} \\
38^{\circ} 27^{\prime} 09^{\prime \prime}, 101^{\circ} 47^{\prime} 04^{\prime \prime}\end{array}$ & $\begin{array}{r}543 \\
1105\end{array}$ & $\begin{array}{l}\text { Harney sil (Typic Argiustolls) } \\
\text { Richfield sil (Aridic Argiustolls) }\end{array}$ & $\begin{array}{l}\text { Scout } 66 \\
\text { Larned }\end{array}$ & $\begin{array}{l}\text { WW } \\
\text { WF }\end{array}$ & $\begin{array}{l}24 \text { Sept. } 1977 \text { (15), } 10 \text { Oct. } 1978(16) \\
9 \text { Sept. } 1977 \text { (17), 8 Sept. } 1978 \text { (18), } \\
\text { 16 Sept. } 1979 \text { (19) }\end{array}$ \\
\hline $\begin{array}{l}\text { Garden City, KS } \\
\text { Medford, OK }\end{array}$ & $\begin{array}{l}38^{\circ} 09^{\prime} 09^{\prime \prime}, 100^{\circ} 46^{\prime} 07^{\prime \prime} \\
36^{\circ} 52^{\prime} 41^{\prime \prime}, 97^{\circ} 40^{\prime} 19^{\prime \prime}\end{array}$ & $\begin{array}{l}892 \\
376\end{array}$ & $\begin{array}{l}\text { Ulysses sil (Aridic Haplustolls) } \\
\text { Renfrow sil (Udertic Paleustolls) }\end{array}$ & $\begin{array}{l}\text { Centurk } \\
\text { TAM 101 }\end{array}$ & $\begin{array}{l}\mathbf{W F} \\
\mathbf{W w}\end{array}$ & $\begin{array}{l}19 \text { Sept. } 1977 \text { (20), } 17 \text { Sept. } 1979 \text { (21) } \\
28 \text { Sept. } 1977 \text { (22), } 27 \text { Sept. } 1978 \text { (23) }\end{array}$ \\
\hline
\end{tabular}

+ Rotation: WF, wheat-fallow; WW, continuous wheat.

$\$$ Number in parentheses denotes the site-year number used in Fig. 4.

$\$$ For Fort Collins, the first number for a year refers to conventional tillage and the second number to no-tillage.

II Dates in italics: the site-year was used in calibration of growing degree-days and not used in validation.

logic, predicting wheat phenology for different tillage or residue management practices, which can alter nearsurface soil temperature, might be improved by using soil temperature when the shoot apex is in the crown.

Air temperature data are more readily available and more easily collected than soil temperature data. Soil temperature at crown depth may be measured, or estimated from air temperature using models, but data collection can be expensive, and model use can require significant effort and lack accuracy, especially when predicting dynamic near-surface soil temperatures for different conditions and management practices.

The foregoing discussion suggests that under some circumstances soil temperature, rather than the traditionally used air temperature, may be better for calculating thermal time in predicting wheat phenology. However, before advocating a switch to soil temperature, the validity of the logic presented above should be tested to determine the potential for improvement in wheat phenology prediction. Therefore, our objective was to evaluate the accuracy of wheat phenology predictions based on soil and air temperature and observed phenological stage data collected over a wide range of conditions and cultivars and using a simple, but common, form of the growing degree-day equation.

\section{MATERIALS AND METHODS}

A data set was assembled containing 23 site-years of phenology measurements from several locations throughout the Central Great Plains of the USA (Table 1). A site-year comprised observations from one of eight sites (soils), six years, five cultivars, and several management practices (e.g., row spacing, fertilizer rates, rotations). For each site-year, dates of seeding, $50 \%$ seedling emergence, and $50 \%$ of the main stems reaching initiation of tillering (when tillers first were visible; Feekes Stage 2), spring green-up, jointing (Feekes Stage 6), heading (Feekes Stage 10.1), kernel in milk (Feekes Stage 11.1), kernel in hard dough (Feekes Stage 11.2), and ripe to cut (Feekes Stage 11.4) were recorded (Large, 1954). A more complete description for most of the site-years can be found in McMaster and Smika (1988).

Daily maximum and minimum air temperatures were measured $1.5 \mathrm{~m}$ above the soil surface using a Class A weather station. Soil temperatures were measured at 2 (site-years 1-4) or 3 (all other site-years) $\mathrm{cm}$ below the soil surface, using thermocouples. This depth was chosen because the crown is usually centered about $2.5 \mathrm{~cm}$ below the soil surface in the Central Great Plains (McMaster, 1997). Thermal time was calculated as growing degree-days (Method 1, McMaster and Wilhelm, 1997) as follows:

$$
\begin{gathered}
T_{\text {avg }}=\frac{T_{\max }+T_{\min }}{2} \\
\mathrm{GDD}=T_{\text {avg }}-T_{\text {base }} \\
\text { if } T_{\text {avg }}<T_{\text {base }}, \text { then } T_{\text {avg }}=T_{\text {base }}
\end{gathered}
$$

$T_{\text {base }}$ was set equal to $0^{\circ} \mathrm{C}$ (McMaster, 1997; McMaster and Smika, 1988).

One year from each of seven sites (Table 1, italics) was chosen to estimate accumulated thermal time (in GDD) from seeding or from 1 January to observed growth stages. The mean of these accumulated GDD for each growth stage over all seven site-years was then used to predict the occurrence of the growth stage for the remaining site-years. We used 1 January because we assumed plants were fully vernalized by that date (Rickman and Klepper, 1991).

Four statistics were used to estimate which temperature provides the better prediction: (i) paired $t$-test to determine if differences existed between using soil and air temperatures for prediction; (ii) simple linear regressions were computed to determine the $r^{2}$; (iii) percentage of predicted dates within $7 \mathrm{~d}$ of the observed date were counted; and (iv) root mean square error (RMSE), with associated sum of the residuals (SRES) and sum of the absolute residuals (SARES) as described by McMaster et al. (1992). These measures give an indication of the variability around the mean and tendency for prediction bias. For example, if there is close agreement between predicted and observed dates, then the RMSE will be small. If SRES is small compared with SARES, errors in the prediction tend to cancel, suggesting no bias of consequence. If there is a considerable bias towards over- or underpredicting the growth stage, then SRES and SARES will be large. Overprediction is indicated by a large negative SRES; underprediction by a large positive SRES.

\section{RESULTS}

When considering all four statistics (paired $t$-test, $r^{2}$, percentage of predicted points within $7 \mathrm{~d}$ of the observed day, and RMSE), there were no instances when using soil temperature significantly improved our predictive accuracy compared with using air temperature (Table 
Table 2. Statistics comparing use of air $\left(T_{\text {air }}\right)$ or soil ( $\left.T_{\text {soil }}\right)$ temperatures to calculate growing degree days between selected wheat growth stages for the validation data sets. $\dagger$

\begin{tabular}{|c|c|c|c|c|c|c|c|c|c|c|c|}
\hline \multirow{2}{*}{$\begin{array}{l}\text { Developmental } \\
\text { interval } \neq\end{array}$} & \multirow{2}{*}{$\begin{array}{c}\text { Site- } \\
\text { years } \$\end{array}$} & \multicolumn{2}{|c|}{$r^{2}$} & \multicolumn{2}{|c|}{$\%$ within \pm 7 d } & \multicolumn{2}{|c|}{ RMSE } & \multicolumn{2}{|c|}{ SRES } & \multicolumn{2}{|c|}{ SARES } \\
\hline & & $T_{\text {air }}$ & $T_{\text {soil }}$ & $T_{\text {air }}$ & $T_{\text {soll }}$ & $T_{\text {air }}$ & $T_{\text {soil }}$ & $T_{\text {air }}$ & $T_{\text {soil }}$ & $T_{\text {air }}$ & $T_{\text {soil }}$ \\
\hline & no. & & & 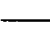 & - - & & & 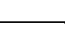 & & & \\
\hline $\mathbf{S}-\mathbf{E}$ & 13 & 0.83 & 0.74 & 85 & 85 & 4.4 & 5.5 & 17 & 23 & 43 & 49 \\
\hline S-TI & 11 & 0.60 & 0.61 & 73 & 64 & 7.0 & 6.7 & -15 & -13 & 55 & 55 \\
\hline $\mathbf{S}-\mathbf{J}$ & 15 & 0.04 & 0.03 & 40 & 53 & 19.3 & 17.7 & 56 & 75 & 219 & 180 \\
\hline $\mathbf{S}-\mathbf{H}$ & 15 & 0.18 & 0.28 & 27 & 40 & 13.3 & 12.0 & -26 & -16 & 176 & 148 \\
\hline $\mathbf{S}-\mathbf{K M}$ & 10 & 0.49 & 0.32 & 50 & 40 & 12.9 & 12.7 & 64 & 63 & 112 & 107 \\
\hline S-KD & 6 & 0.53 & 0.51 & 50 & 67 & 7.7 & 14.4 & 28 & -10 & 42 & 56 \\
\hline $\mathbf{S}-\mathbf{M}$ & 15 & 0.51 & 0.40 & 47 & 53 & 9.6 & 11.0 & 21 & -31 & 116 & 116 \\
\hline 1 Jan.-SG & 11 & 0.06 & 0.07 & 27 & 55 & 16.0 & 13.1 & 30 & -10 & 148 & 112 \\
\hline 1 Jan.-J & 15 & 0.00 & 0.00 & 47 & 47 & 13.7 & 13.4 & 17 & -9 & 179 & 171 \\
\hline 1 Jan.-H & 15 & 0.13 & 0.27 & 47 & 60 & 8.9 & 11.3 & -48 & -84 & 114 & 130 \\
\hline 1 Jan.-KM & 11 & 0.59 & 0.17 & 55 & 36 & 7.9 & 13.7 & -39 & -87 & 69 & 107 \\
\hline 1 Jan.-KD & 5 & 0.00 & 0.05 & 80 & 80 & 8.4 & 5.6 & 27 & 17 & 35 & 21 \\
\hline 1 Jan.-M & 13 & 0.55 & 0.52 & 69 & 69 & 7.5 & 6.9 & 25 & 3 & 68 & 68 \\
\hline
\end{tabular}

+ RMSE, root mean square error; SRES, sum of residuals; SARES, sum of absolute residuals. For paired $t$-test results, see Fig. 2 and 3.

†rowth stages: S, seeding; E, emergence; TI, beginning tiller initiation; SG, spring green-up; J, jointing; H, heading; KM, kernel in milk; KD, kernel in dough; $M$, physiological maturity. 1 Jan. represents vernalization complete.

$\S$ Site-years are described in Table 1.

2). The greatest improvement from using soil temperatures came in predicting heading, either from seeding or from 1 January (except for the RMSE; Table 2). Even though heading is defined by the spike, or head, emerging from the enfolding flag leaf sheath, the apex is below the soil surface for most of the interval from seeding to heading when time is measured in days or GDD. Based on air temperature, 1258 GDD accumulated from seeding to jointing, but only 398 GDD accumulated from jointing to heading (Table 3). A similar comparison was found for soil temperatures (1277 GDD from seeding to jointing and 433 GDD from jointing to heading). It is also possible that the temperature within the canopy is at least partly influenced by soil temperature, so that soil temperature could still be an important factor, until the spike emerges from the top of the canopy.

The other spring growth stages occurring prior to heading (spring green-up and jointing) were also predicted slightly better by soil temperature, although the evaluation statistics varied considerably (Table 2). Spring green-up is a difficult stage to clearly identify in the field, and jointing is strongly affected by factors other than temperature (McMaster, 1997). Realistically, because spring green-up and jointing were predicted so poorly when using GDD calculated from either air or soil temperature, the slight improvement from using soil temperature is of little consequence.

Predicting the growth stages of emergence and beginning of tiller initiation were not improved by using soil temperature (Table 2). Seedling emergence was predicted equally well by using either air or soil temperature, and the only instances when the GDD model did not predict emergence well was when soil water was insufficient for imbibition and germination.

For growth stages after heading (kernel in milk, kernel in dough, and maturity), most evaluation statistics indicated that using air temperature was as good as, or slightly better, than using soil temperature (Table 2). This tendency was most noticeable when beginning GDD accumulation at seeding. Caution is needed when examining the kernel in dough evaluation, because only 6 site-years documented this stage.

Predicted date of occurrence of a growth stage for each site-year using air or soil temperature compared with the observed date (Fig. 1 and 2) confirms the validation results presented in Table 2. Associated pairs of air and soil predictions from each site-year can be located in the figures by looking for the points plotted on the same observed date. Occasionally several site-years have the same observed date, but the paired air and soil temperature results are the ones closest to each other. In every

Table 3. Comparison of accumulated air and soil growing degree days (GDD) for selected wheat growth stage intervals (means of 22 or 23 site-years).

\begin{tabular}{|c|c|c|c|c|}
\hline $\begin{array}{l}\text { Developmental } \\
\text { interval } \dagger\end{array}$ & $\begin{array}{c}\text { Mean date, } \\
\text { end of interval }\end{array}$ & GDD $_{\text {gir }}$ & GDD $_{\text {soil }}$ & $\mathbf{G D D}_{\text {air }}-\mathbf{G D D}_{\text {sail }}$ \\
\hline $\begin{array}{l}\text { S-E } \\
\text { E-TI } \\
\text { TI-1 Jan. } \\
\text { 1 Jan.-SG } \\
\text { SG-J } \\
\text { J-H } \\
\text { H-KM } \\
\text { KM-KD } \\
\text { KD-M }\end{array}$ & $\begin{array}{l}24 \text { Sept. } \\
5 \text { Oct. } \\
1 \text { Jan. } \\
9 \text { Mar. } \\
2 \text { May } \\
1 \text { June } \\
12 \text { June } \\
27 \text { June } \\
7 \text { July }\end{array}$ & \begin{tabular}{|r|r|}
154 \\
178 \\
437 \\
70 \\
419 \\
398 \\
204 \\
411 \\
136
\end{tabular} & $\begin{array}{r}171 \\
181 \\
438 \\
45 \\
442 \\
4433 \\
188 \\
443 \\
126\end{array}$ & $\begin{array}{r}-17 \\
-3 \\
-1 \\
25 \\
-23 \\
-35 \\
16 \\
-32 \\
10\end{array}$ \\
\hline Total & & 2407 & 2467 & -60 \\
\hline
\end{tabular}

$\dagger$ Growth stages: S, seeding; E, emergence; TI, beginning tiller initiation; SG, spring green-up; J, jointing; H, heading; KM, kernel in milk; KD, kernel in dough; $M$, physiological maturity. 1 Jan. represents vernalization complete. 


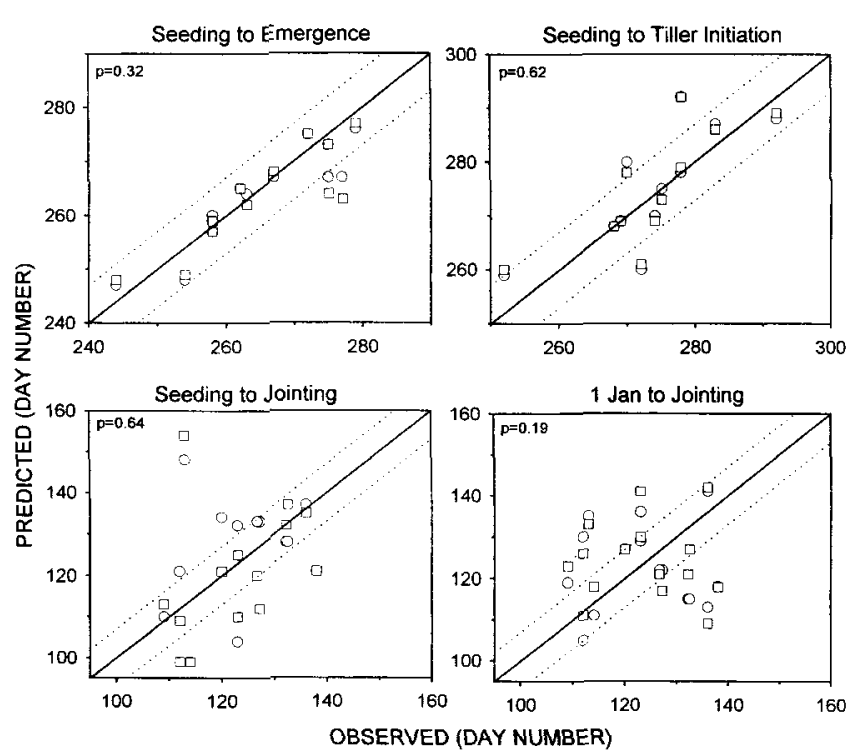

Fig. 1. Validation results for predicting emergence, beginning of tiller initiation, and jointing using air temperature (circles) or soil temperature (squares). The solid line is the 1:1 line, with dashed lines representing $\pm 7 \mathrm{~d}$ from the 1:1 line. Paired $t$-test results for using soil and air temperatures to predict the growth stage are presented in the upper left corner of each graph.

figure, it is apparent that for a portion of the site-years all possible outcomes occurred; that is, using air temperature was better, no different, or worse than using soil temperature. For example, in Fig. 1 (seeding to emergence), there are four instances when air temperature is better than soil temperature (circles closer to the 1:1 line than squares), five when there is no difference between air and soil temperature (circles and squares same distance from the 1:1 line), and four when air temperature is worse than soil temperature (squares closer to the 1:1 line than circles). Paired $t$-test results confirm this visual analysis, as there were no instances of significant differences in predicting a growth stage by using soil or air temperatures (results are presented in Fig. 1 and 2).

Bias towards predicting a growth stage early or late can be assessed by examining SRES and SARES (Table 2 ). With only a few slight exceptions, bias was not observed for either the air or soil temperature models. Both models tended to predict seeding to jointing and kernel in milk, and 1 January to kernel in dough, a little early. Both air and soil temperature models tended to predict the interval from 1 January to heading and kernel in milk later than it actually occurred. The air temperature model tended to predict thermal time to maturity (either from seeding or 1 January) earlier than it was observed, while the soil temperature model tended to predict seeding to maturity too late.

The close similarity of accumulated GDD of air and soil is somewhat surprising. When calculating mean GDD from 23 site-years from seeding to maturity, a period of almost $10 \mathrm{mo}$, soil accumulated only $60 \mathrm{GDD}$ more than air, or about $2 \%$ of the total (Table 3 ). If intervals within the life cycle are examined, from seeding to 1 January, soil accumulated 21 GDD more than air, with most of the difference (17 GDD) occurring from

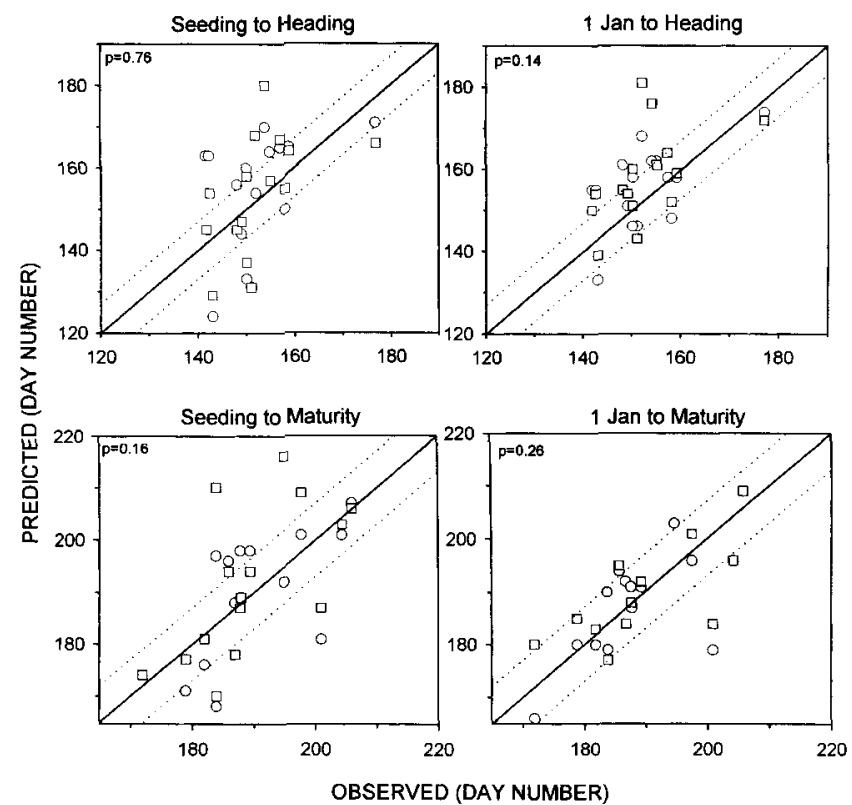

Fig. 2. Validation results for predicting heading and maturity using air temperature (circles) or soil temperature (squares). The solid line is the 1:1 line, with dashed lines representing $\pm 7 \mathrm{~d}$ from the 1:1 line. Paired $t$-test results for using soil and air temperatures to predict the growth stage are presented in the upper left corner of each graph.

seeding to emergence. From seeding to heading, soil temperature (1898 GDD) accumulated slightly more GDD than air (1860 GDD). Differences between the two bases for calculating thermal time were always a very small proportion (usually $<7 \%$ ) of the accumulated GDD for either a specific interval or the total GDD accumulated for the season to that event. After heading, air accumulated more GDD than soil, except for the period from kernel in milk to kernel in dough. Again, the difference was small.

Perhaps the reason for greater soil GDD accumulation from seeding through heading can be explained by canopy development. Near-surface soil temperature is affected by canopy development, which alters the amount of radiation reaching the soil surface and the wind speed over the soil. Until shortly before jointing, the wheat plant is in a rosette form with small leaf area index (LAI) and little ground cover. Also, many leaves produced in fall senesce during winter, further reducing LAI. At Feekes Stage 5, leaf sheath elongation begins, and at jointing internode elongation causes plant height to increase quickly. Near the time of flag leaf appearance (early booting), LAI reaches its maximum and canopy cover and height are greatest. Near the time of heading, LAI begins to decline, allowing more radiation to reach the soil surface, but wind speed over the soil surface is reduced by the standing culms. The combined impact of these plant structures and aerodynamic factors may explain the observed differences in GDD accumulation.

Consistency among site-years in accumulation of soil and air GDD (Table 3) varied, depending on the interval considered. Variation in accumulated GDD for selected intervals among the site-years is presented in Fig. 3. The most consistent relationship between soil and air 


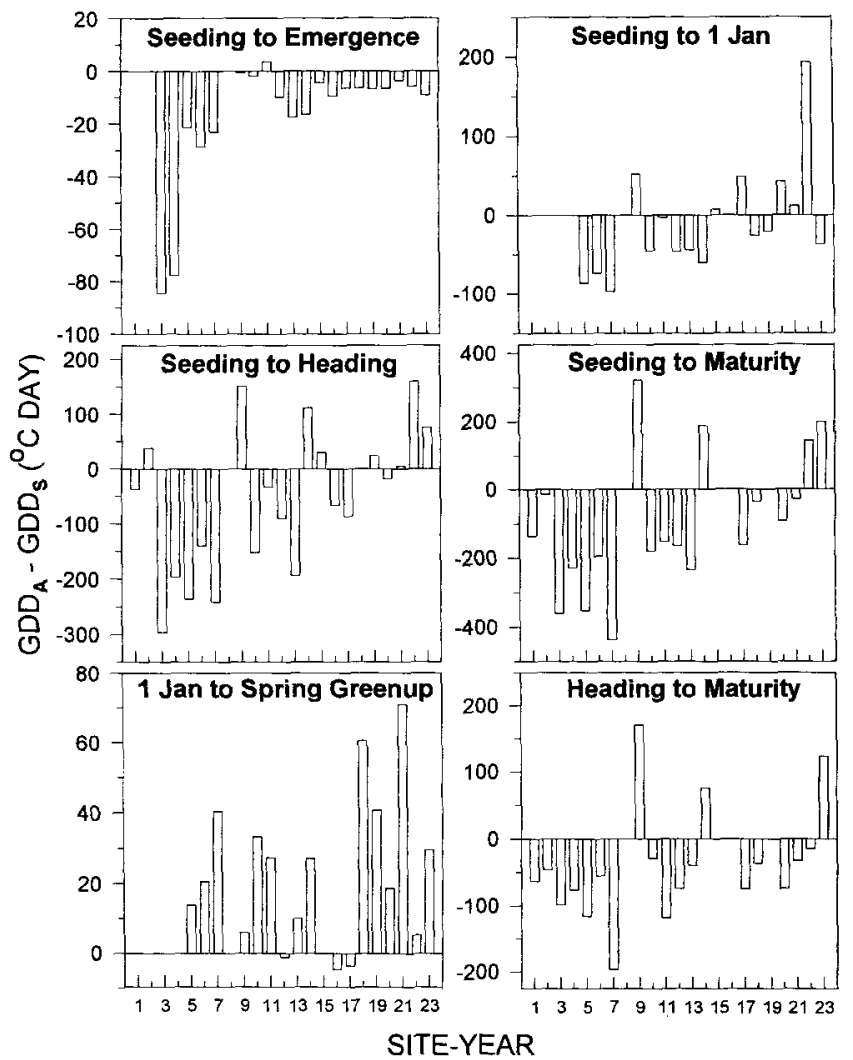

Fig. 3. Comparison of air and soil growing degree days (GDD) over a specific time interval for each site-year. See Table 1 for site-year number designations.

temperature was for the interval from seeding to emergence, when soil accumulated more GDD than air in 19 of the 20 site-years $(95 \%)$. For the intervals from heading to maturity, $84 \%$ of the site-years showed greater soil temperature-based GDD accumulation, but for the site-years where this was not true the difference was great (>50 GDD). For the 1 January to spring green-up interval, $82 \%$ of the site-years show greater GDD accumulation for the air-temperature-based calculation. The three deviations from this pattern were very slight ( $<5$ GDD). Seeding to maturity $(79 \%$ ), seeding to 1 January $(65 \%)$, and seeding to heading $(64 \%)$ were consistent as to which basis of GDD calculation produced the greater sum most frequently. The 1 January to jointing interval had the least consistent relationship between air and soil temperature (data not shown); half of the time, air accumulated more than soil, and half the time the opposite occurred. The times that airtemperature-based calculation accumulated more GDD than soil-based calculation resulted in a much smaller mean difference in GDD accumulated than was noted in Fig. 3 from heading to maturity.

Some of the similarity between accumulated GDD based on air and soil temperature may be a result of the algorithm used in the calculation. Whenever $T_{\text {avg }}$ (Eq. [2]) is less than $T_{\text {base }}$, no GDD accumulate, regardless of the observed air or soil temperature. This results in greater similarity in accumulated air and soil GDD than exists in observed air and soil temperatures.

\section{DISCUSSION}

Results of this investigation do not support our initial hypothesis that use of soil temperature as the basis for GDD calculation would improve our ability to predict winter wheat phenological stage from accumulated thermal time estimates. Unpublished data of Klepper and Rickman (personal communication, 1997) in the Pacific Northwest showed identical results. There are several explanations why we observed no improvement in our predictive accuracy by using soil temperature. First, pooling the site-year data across diverse cultivars, soils, management practices, and climates may have masked subtle improvements. If so, then indeed the improvement by using soil temperature is too slight for concern. Further, when examining Fig. 1 and 2, the predictions using soil and air temperature for individual site-years were usually similar and using air temperature was as likely to be closer to the observed date. Therefore, pooling site-years doesn't appear to explain why soil temperature did not improve the predictive accuracy. An alternative explanation could be the specific GDD calculation we chose. However, this method is used commonly by practitioners and in models, so if a change in the temperature upon which the calculation is based is to be useful in the field it needs to be applied to commonly used algorithms. We suggest that the main explanation for our results is that, regardless of whether air or soil temperature is used to calculate GDD, a consistent relationship with shoot apex temperature is assumed. From our work, this relationship normally holds equally well for both air or soil temperature. When calculating the GDD based on soil temperature, the only difference is the number of GDD accumulated, but the basic relationship with apex temperature does not change, so the predictive accuracy remains the same. Couple this with the fact that accumulated air and soil GDD were very similar in our data set (Table 3 ) and many of the intervals were consistent in GDD accumulation differences between air and soil by site-years (Fig. 3), there is little reason to expect that using soil temperature will significantly improve our predictive accuracy. In fact, regression of GDD computed from air temperature on GDD computed from soil temperature showed that from 70 to $90 \%$ of the variation in GDD calculated from soil temperature data was explained by variation in GDD from air temperature. With this great correlation between the two measures of thermal time, it is not surprising that they produced nearly equal predictions and using soil temperatures did not measurably improve estimates.

Our work is based on some relatively broad phenological stages. Several researchers, working with precisely defined stages during vegetative development, such as leaf stages (Bollero et al., 1996; Jamieson et al., 1995; Ong, 1983; Peacock, 1975) and seedling emergence rates and tillering (Addae and Pearson, 1992; Ong, 1983), have reported that soil temperature provides greater predictive accuracy. Unless special instances such as emergence rates and leaf and tiller appearance are being considered, our results suggest that no significant benefit 
is derived from using soil temperature rather than air temperature for predicting winter wheat phenology.

\section{ACKNOWLEDGMENTS}

The authors wish to thank Mr. Daniel Palic for technical assistance.

\section{REFERENCES}

Addae, P.C., and C.J. Pearson. 1992. Thermal requirements for germination and seedling growth of wheat. Aust. J. Agric. Res. 43: 585-594.

Bollero, G.A., D.G. Bullock, and S.E. Hollinger. 1996. Soil temperature and planting date effects on corn yield, leaf area, and plant development. Agron. J. 88:385-390.

Frank, A.B., and A. Bauer. 1995. Phyllochron differences in wheat, barley, and forage grasses. Crop Sci. 35:19-23.

Kleinendorst, A., and R. Brouwer. 1970. The effect of temperature of the root medium and of the growing point of the shoot on growth, water content and sugar content of maize leaves. Neth. J. Agric. Sci. 18:140-148.

Jamieson, P.D., I.R. Brooking, J.R. Porter, and D.R. Wilson. 1995. Prediction of leaf appearance in wheat: A question of temperature. Field Crops Res. 41:35-44.

Large, E.C. 1954. Growth stages in cereals. Plant Pathol. 3:128-129.

McMaster, G.S. 1997. Phenology, development, and growth of the wheat (Triticum aestivum L.) shoot apex: A review. Adv. Agron. 59:63-118.

McMaster, G.S., and D.E. Smika. 1988. Estimation and evaluation of winter wheat phenology in the Central Great Plains. Agric. For Meteorol. 43:1-18.
McMaster, G.S., and W.W. Wilhelm. 1997. Growing degree-days: One equation, two interpretations. Agric. For. Meteorol. 87:291-300.

McMaster, G.S., W.W. Wilhelm, and J.A. Morgan. 1992. Simulating winter wheat shoot apex phenology. J. Agric. Sci., Camb. 119:1-12.

Ong, C.K. 1983. Response to temperature in a stand of pearl millet (Pennisetum typhoides S. \& H.). J. Exp. Bot. 34:322-336.

Peacock, J.M. 1975. Temperature and leaf growth in Lolium perenne: II. The site of temperature perception. J. Appl. Ecol. 12:115-123.

Purvis, O.N. 1961. The physiological analysis of vernalisation. Handb. Pflanzenphysiol. 16:76-122.

Rickman, R.W., and E.L. Klepper. 1991. Tillering in wheat. p. 73-84. In T. Hodges (ed.) Plant phenology. CRC Press, Boca Raton, FL.

Rickman, R.W., S. Waldman, and B.L. Klepper. 1996. MODWht3: A development-driven winter wheat growth simulation. Agron. J. 88:176-185.

Ritchie, J.T., and S. Otter. 1985. Description and performance of CERES-Wheat: A user oriented wheat yield model. p. 159-175. In W.O. Willis (ed.) ARS Wheat Yield Project. ARS-38. USDAARS, Washington, DC.

Sato, K., and M. Ito. 1968. Growth responses to air and soil temperature of orchard grass and perennial ryegrass. Proc. Crop Sci. Soc. Jpn. 38:313-320.

Watts, W.R. 1972. Leaf extension in Zea mays: II. Leaf extension in response to independent variation of the temperature of the apical meristem, of the air around the leaves, and of the root-zone. J. Exp. Bot. 23:713-721.

Weir, A.E., P.L. Bragg, J.R. Porter, and J.H. Rayner. 1984. A winter wheat crop simulation model without water or nutrient limitations. J. Agric. Sci., Camb. 102:371-382.

Wilhelm, W.W., and G.S. McMaster. 1995. The importance of the phyllochron in studying the development of grasses. Crop Sci. 35:1-3. 